\title{
Kızılçam (Pinus brutia Ten.)'da orijinlere bağlı morfolojik varyasyonlar
}

\author{
Zafer Yücesan ${ }^{\mathrm{a}, *}$ (D), Ali Deniz Y1ldırım ${ }^{\mathrm{b}}$ (i)
}

\begin{abstract}
Özet: Kızılçam (Pinus brutia Ten.) Türkiye ormanlarında en geniş doğal yayılış alanına sahip çam türüdür. Ekonomik ve ekolojik açıdan oldukça büyük bir öneme sahiptir. Küresel iklim değişikliği senaryolarına bağlı olarak ekolojik ırkların belirlenmesi ve ekolojik ırklara bağlı olarak kitlesel kaliteli fidan üretimi oldukça önemlidir. Kaliteli fidan üretimi, başta verimsiz alanların ıslahı olmak üzere ağaçlandırma çalışmalarının başarısında önemli etkenlerden birisidir. Bu çalışmada, Antalya Orman Fidanlığında 6 farklı orjinden elde edilen $1+0$ yaşındaki çıplak köklü kızılçam fidanlarında fidan boyu, fidan kök boğazı çapı, yan sürgün sayısı, ortalama yan sürgün boyu, tepe sürgünü boyu, dalsı gövde boyu, tepe tomurcuğu sayısı ve gürbüzlük derecesi belirlenmiştir. Elde edilen veriler doğrultusunda orjinler arasında morfolojik özellikler açısından farklılıkların olup olmadığı analiz edilmiștir. Ayrıca Türk Standartları Enstitüsü fidankalite sınıflandırmasına göre fidan sınıflandırılması yapılarak morfolojik özellikler ile fidan kalite sınıfları arasındaki ilişkiler irdelenmiştir. Çalışmada 6 orijinden 3 tekrarlı olacak şekilde 100'er adet, toplamda 1800 fidanda ölçümler gerçekleştirilmiștir. Orijinlerin morfolojik özellikleri açısından istatistiksel olarak anlamlı $(p<0.05)$ farklılıklara sahip oldukları belirlenmiştir. Elde edilen veriler morfolojik özellikler açısından fidan boyu ve kök boğazı çapı ile birlikte tomurcuk sayısı ve yan sürgün boyu özelliklerinin de kalite sınıflandırmasında anlamlı sonuçlar verebileceğini göstermiştir.

Anahtar kelimeler: Kızılçam, orijin, fidan morfolojisi, kalite sınıflandırması
\end{abstract}

\section{Morphological variations in origins of Turkish red pine (Pinus brutia Ten.)}

\begin{abstract}
Turkish red pine (Pinus brutia Ten.) is a tree species with the widest distribution area among pine species in Turkey. In terms of wood production Turkish red pine has huge economic economic and ecological importance. Identification of ecological races and mass seedling production on the basis of ecological races are very important deal with the climate change. Production of quality seedlings is one of the important factors in the success of afforestation studies, especially in the improvement of unproductive areas. In this study, sapling length, sapling root collar diameter, number of lateral shoots, average length of the lateral shoots, terminal shoot length, stem height without shoots, number of terminal buds were measured in $1+0$ year old seedlings obtained from 6 different origins and located in Antalya Forest Nursery. By obtained results, it was analyzed whether there were differences in terms of morphological features between the origins. Measurements were carried out on 100 saplings from 6 origins with 3 replication, and in total 1800 saplings were measured. It was determined that the seedlings have statistically significant differences in terms of morphological characteristics depending on the origin. Obtained data showed that number of terminal buds and lateral shoot length can give significant results in quality classification in terms of morphological characteristics beside seedling height and root collar diameter.
\end{abstract}

Key words: Turkish red pine, origin, seedling morphology, quality classification

\section{Giriş}

Ormanlar, üstlenmiş oldukları ekonomik, ekolojik ve sosyal fonksiyonları ile son derece önemli ölçülebilen ve ölçülemeyen değerler ortaya koymaktadır. Ekonomik, ekolojik ve sosyal açıdan son derece önemli fonksiyonları yerine getiren büyük ve hareketli ekosistemin korunması, geliştirilmesi ve sürdürülebilir bir ormancılık yapılabilmesi için, doğal gençleştirmenin yanısıra, gerek yapay gençleştirme gerekse de rehabilitasyon çalışmalarında kullanılabilecek ekim kültürlerinin uygun orijinlerden elde edilecek tohum materyalleri ile tesis edilmesi silvikültürel açıdan oldukça önemlidir.

Türkiye ormanlarının, 13.264.429 hektarı normal kapalı (\%57.84) ve 9.668.571 hektarı boşluklu kapalı orman alanı vasfinda olup (\%42.16) (Anonim 2020), boşluklu kapalı orman formunda olan bu alanlar kendilerinden beklenen ekonomik, ekolojik ve sosyal fonksiyonları yerine getirememektedir. 1973 yılı itibarıla Türkiye orman alanlarındaki toplam yıllık artım 28 milyon $\mathrm{m}^{3}$ iken; bu miktar 2020 yılı itibarıla 47,4 milyon $\mathrm{m}^{3}$ 'e ulaşmıştır (Anonim 2020). Söz konusu bu artış, koru ormanlarının toplam orman alanlarındaki payının artması, ağaçlandırma çalışmaları ile yeni orman alanlarının oluşturulması ve ormanlardaki bakım çalışmalarının daha etkin hale getirilmesi ile açıklanmaktadır (Anonim 2020). Nitekim Boydak ve Çalışkan (2014), Türkiye ormancılığı açısından verimsiz orman alanlarının ağaçlandırma çalışmaları ile verimli hale getirilmesi, uygun alanlarda hızlı gelişen türlerle endüstriyel ağaçlandırma çalışmalarının gerçekleştirilmesi ile ormanlarda artımın yaklaşık iki katına çıkarılması ve yıllık etanın çok daha yüksek seviyelere taşınabilmesinin mümkün olabileceğini ifade etmiştir.

Türkiye orman alanları içinde Kızılçam (Pinus brutia Ten.) 5.736.371 hektarlık yayılışı ile önemli bir paya ve iğne yapraklılar içinde en geniş yayılışa sahiptir. Ancak, mevcut Kızılçam ormanlarının \% 37.6'sı, boşluklu kapalı yani bozuk orman niteliğindedir (www.ogm.gov.tr 2020). Diğer taraftan, Türkiye'de ağaçlandırma yoluyla kurulan

\footnotetext{
Orman Mühendisliği Bölümü, Orman Fakültesi, Karadeniz Teknik Üniversitesi, Trabzon

b Taşağıl Orman İşletme Müdürlüğü, Antalya

* Corresponding: yucesan@ktu.edu.tr

Received: 11.05.2021, Accepted: 20.05.2021
}

Citation: Yücesan Z, Yıldırım A.D (2021). Kızılçam (Pinus brutia Ten.)'da orijinlere bağlı morfolojik varyasyonlar. Theoretical and Applied Forestry 1: 17-26.

doi: 10.53463/tafor.2021vol1iss1pp17-26 
1.763.472 ha orman alanı içerisinde Kızılçamın 706.989 ha ağaçlandırma sahası ile ilk sırada yer aldığı ifade edilmiştir (Çoşgun vd., 2008). Boydak vd.(2006) ise kızılçam ağaçlandırmalarının toplam kızılçam ormanları içerisinde \%16.8 gibi önemli bir orana sahip olduğunu belirtmiştir.

Küresel iklim değişikliğinin biyolojik çeşitlilik kaybının ana nedenlerinden biri olacağı pek çok yayında ifade edilmektedir (Sala vd. 2000; Anonim 2005; Pawson vd. 2013). Ayrıca, iklim değişikliğinin birçok türün neslinin tükenmesiyle sonuçlanacağına dair ikna edici kanıtlar mevcuttur (Thomas vd. 2004). Ağaçların ve dolayısıyla orman ekosistemlerinin ise, diğer organizmalara nispeten uzun ömürlü olmaları ve hızlı çevresel değişimlere yanıt verebilmek için sınırlı uyarlanabilir kapasiteye sahip olmalarından dolayı iklim değişikliğine çok daha duyarlı oldukları da ifade edilmektedir (Lindner vd. 2010). Dolayısıyla, küresel iklim değişikliği senaryolarına uygun olarak, iklim değişikliğine dayanıklı orijinlerin tespiti türlerin devamlılığı açısından da oldukça önemlidir.

Verimsiz ormanların 1slahı açısından hangi özellik ya da özellikler bakımından elit ağaçlardan elde edilen tohumun üstün ve adaptasyon kabiliyetinin yüksek olduğunun tespit edebilmesi gerekir. Selekte edilmiş fidan materyalleri kullanıldığında, tohum meşcerelerinde $\% 20$, tohum bahçelerinde $\% 30$ ve çelikle üretimde $\% 40$ civarında bir genetik kazanç beklendiği belirtilmiştir (Ürgenç 1982). Gerçekleştirilmiş olan bu tür bilimsel araştırmalar ile sahip olunan genetik çeşitliliğin ve kalitenin nicelik olarak tespit edilmesi, önemli özelliklere sahip orijinlerin saptanması ve bunun sonucunda ise gerçekleştirilmesi hedeflenen ıslah çalışmalarında bu orijinlerin kullanılması ormancılık açısından son derece önemli olduğu kadar, ileriki yıllarda yapılacak olan çalışmalara da yol gösterici olacaktır (Yahyaoğlu ve Atasoy 1983; Yahyaoğlu ve Atasoy 1988; Üçler vd. 2000; Deligöz vd. 2009; Ş1klar vd. 2017).
Fidanların morfolojik ve genetik özellikleri, gerek ağaçlandırma çalışmalarının başarısı üzerinde gerekse de ağaçlandırma çalışmalarının maliyetlerinin azaltılmasında oldukça önemli kriterlerdir (Şıklar vd. 2017). Diğer taraftan fidan boyunun diri örtü mücadelesi, kök boğazı çapının kurak ve yarı kurak alanlardaki ağaçlandırma çalışmalarının başarısı ve fidan boyu/kök boğazı çapı oranının ise gerek fidan gelişimi gerekse de hayatta kalma açısından oldukça önemli olduğu bilinmektedir (Bilir vd. 2010). Yapılan bu çalışma kapsamında ağaçlandırma çalışmalarında genellikle $1+0$ kızılçam fidanlarının kullanıldığı düşünüldüğünde farklı orijinler bazında fidanların morfolojik özelliklerinin değişimleri analiz edilerek türün genetik-1slah, fidanlık tekniği ve fidan kalite sınıflandırmasına katkı sağlanması hedeflenmiştir.

\section{Materyal ve metot}

\subsection{Materyal}

Yapılan çalışmada farklı orijinlere bağlı morfolojik varyasyonların belirlenmesi amaciyla Antalya Orman Fidanlığında 6 orijinden elde edilmiş tohumların ekilmesiyle elde edilen 1+0 yaşındaki çıplak köklü kızılçam fidanları materyal olarak kullanılmıştır (Şekil 1). Tohumlar Orman Genel Müdürlüğü tarafindan toplanmış ve Antalya Orman Fidanlığında ekim yastıklarına orijin farklılıklarını dikkate alacak şekilde ekilmiştir. Ekim yastıklarında herhangi bir seyreltme işlemi gerçekleştirilmemiştir. Fidanların elde edildiği tohumların ait oldukları orijinlerin genel bilgileri Tablo 1 'de verilmiştir.

Çalışma kapsamında belirlenen 6 farklı orijinden her orijin 3 tekrarlı olacak şekilde (3x100 adet) 300 adet fidan rastgele belirlenmiş ve toplamda 1800 adet fidanda ölçümler gerçekleştirilmiştir.

Tablo 1. Orijinlere ait genel bilgiler

\begin{tabular}{ccccc}
\hline Orijin No & Orijin & Yükselti & Mevki & Bak1 \\
\hline 1 & TB156 & $0-400$ & Antalya-Düzlerçamı & Güney Batı \\
2 & TB19 & $400-800$ & Bucak & Kuzey Doğu \\
3 & Serik TB20 & $400-800$ & Pınargözü & Güney Doğu \\
4 & TB198 & $0-400$ & Genotipik Bahçe (TM6-21-25-32-37-38-39-61-62-354) & Kuzey Doğu \\
5 & TB38 & $800-1200$ & Gündoğmuş-Eskibağ & Doğu \\
6 & TB204 & $0-400$ & Alanya-Karg1 & Güney Bat1 \\
\hline
\end{tabular}



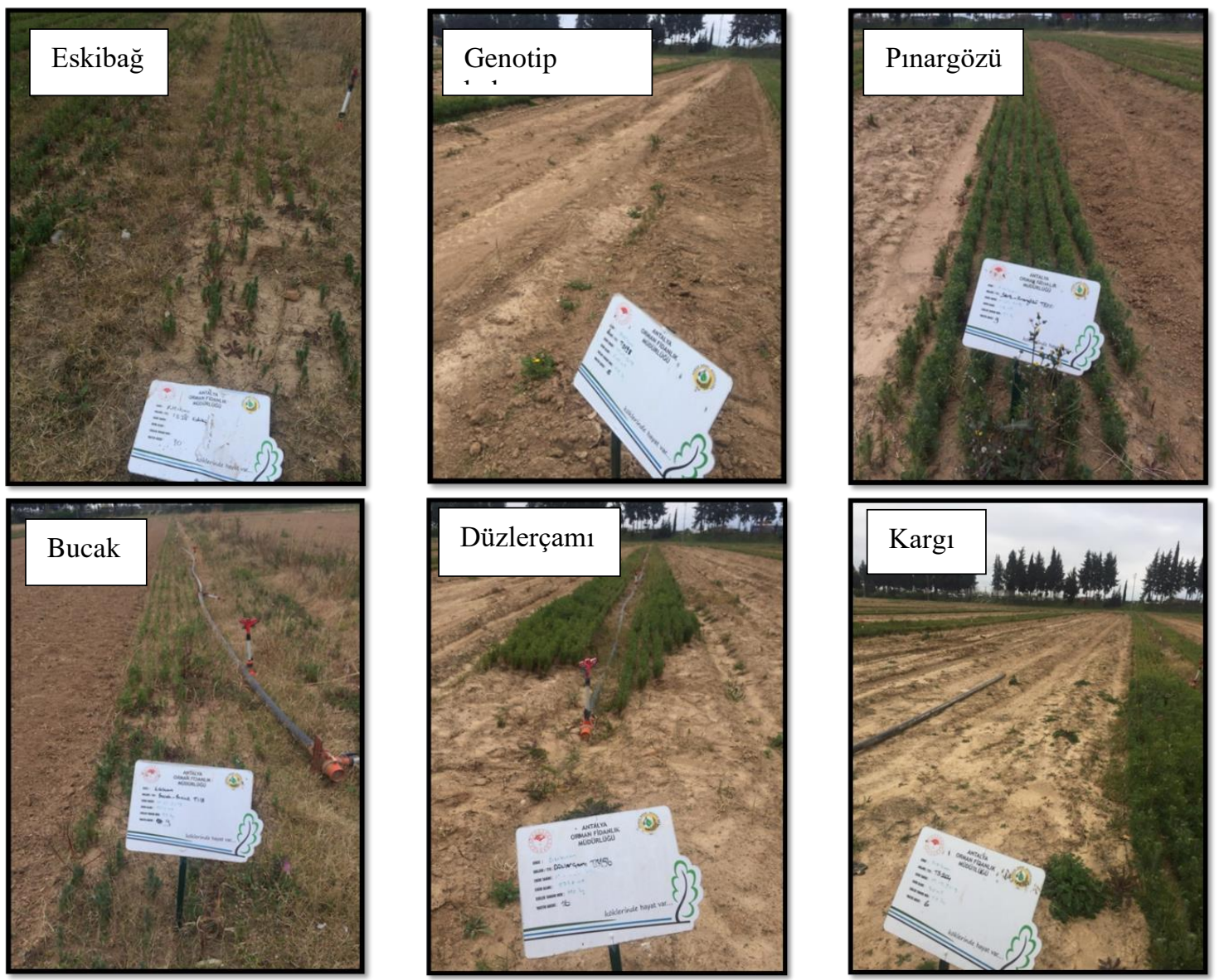

Şekil 1. Orijinlere ait ekim yastıklarının genel görünümü

\subsection{Metot}

Fidanlara ait kök boğazı çapı, fidan boyu, fidan ortalama yan sürgün boyu, fidan tepe sürgün boyu, fidan ilk boyu (dalsız gövde yüksekliği) ve fidan tepe tomurcuk adedi olmak üzere bazı morfolojik özellikleri ölçülmüştür. Kök boğazı çaplarının ölçümü, $0.01 \mathrm{~mm}$ hassasiyetindeki kumpas yardımı ile ölçülmüş ve orijin bazında kök boğazı çapı değişimleri belirlenmiştir. Fidanların boyları, milimetre hassasiyetinde cetvel yardimıyla toprak seviyesinden tepe tomurcuğunun ucuna kadar olan kısmın ölçülmüş ve orijin bazında fidan boylarının değişimleri belirlenmiştir. Fidanların yan sürgün boyları milimetre hassasiyetinde ölçülerek orijinlerin ortalama yan sürgün boyu değişimleri belirlenmiştir. Fidan boyu/kök boğazı çap1 oranına dayanan gürbüzlük indeksinin ana amacı fidan boyu ile gövdesi arasındaki uyumu göstermesidir (Tolay 1983). Fidanların gürbüzlük dereceleri fidan kök boğazı çapının (KBÇ) fidanın boyuna (FB) oranlanması $(\mathrm{FB} / \mathrm{KBÇ})$ ile belirlenmiş ve orijinler arasındaki gürbüzlük derecesi değişimleri tespit edilmiştir. Fidanların tepe sürgünleri milimetre hassasiyetinde ölçülerek orijinler arasında tepe sürgün boyunun değişimi belirlenmiştir. Fidanların toprak seviyesinden ilk yan dalların başlangıç kısmına kadar olan dalsız gövde kısmı milimetre hassasiyetinde ölçülerek orijinler arasında dalsız gövde uzunluğu değişimi belirlenmiştir. Fidanların son yıla ait tepe tomurcuk sayıları belirlenerek orijinler arasında tepe tomurcuğu sayısı değişimi tespit edilmiştir.

\subsection{Istatistiksel değerlendirme}

Morfolojik özelliklerin belirlenmesi soucunda elde edilen veriler SPSS paket programı yardımı ile istatistiksel olarak analiz edilmiştir. Verileri analiz etmede parametrik veya parametrik olmayan yöntemlerin kullanımının kararını vermek için öncelikle normal dağ 11 ım gösterip göstermediklerine bakılmıştır. $\mathrm{Bu}$ kapsamda verilerin çarpıklık ve basıklık değerleri hesaplanmıştır. Ölçek puanlardan elde edilen basıklık ve çarpıklık değerlerinin +2 ile -2 arasında olması normal dağılım için yeterli görülmektedir (George ve Mallery 2010). Normal dağılım gösterdiği tespit edilen verilere ANOVA testi uygulanmıştır. İstatistiksel olarak anlamlı farklılıkların belirlendiği morfolojik özellikler için homojen grupların tespit edilmesi amacıyla Tukey testi uygulanmıştır. Çalışma kapsamında kızılçam fidanlarında ölçülen tüm morfolojik özelliklere ilişkin orijinler arasında meydana gelen gruplar hiyerarşik kümeleme analizi ile belirlenmiştir. $\mathrm{Bu}$ gruplandırmaların anlamlılığı ise ayırma analizi (discriminant) ile test edilmiştir. 


\section{Bulgular}

Fidanların boyu bakımından orijinlerin ortalama değerleri; 1 nolu orijin $12.5 \mathrm{~cm}, 2$ nolu orijin $13 \mathrm{~cm}$, 3nolu orijin $12.4 \mathrm{~cm}, 4$ nolu orijin $16.6 \mathrm{~cm}$, 5nolu orijin $9.7 \mathrm{~cm}$ ve 6 nolu orijin $18.9 \mathrm{~cm}$ olarak hesaplanmıştır. Bu ölçümler sonucunda; en uzun boya sahip orijin $18.9 \mathrm{~cm}$ ile 6 nolu orijin, en kısa boya sahip orijin ise $9.7 \mathrm{~cm}$ ile 5 nolu orijinde elde edilmiştir (Şekil 2). Tüm orijinler bazında genel değerlendirme yapıldığında ise ortalama fidan boyu $13.8 \mathrm{~cm}$ olarak hesaplanmıştır.

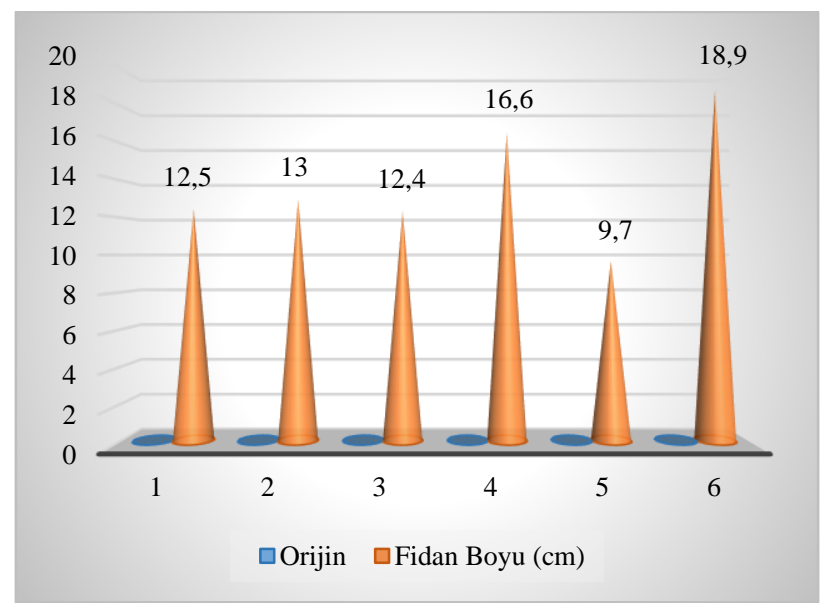

Şekil 2. Orijinlere göre ortalama fidan boyları değişimi

Fidanların kök boğazı çapı bakımından orijinlerin ortalama değerleri; 1 nolu orijin $2.2 \mathrm{~mm}, 2$ nolu orijin $2.26 \mathrm{~mm}, 3$ nolu orijin $2.74 \mathrm{~mm}, 4$ nolu orijin $3.29 \mathrm{~mm}, 5$ nolu orijin $2.02 \mathrm{~mm}$ ve 6 nolu orijin $3.11 \mathrm{~mm}$ olarak hesaplanmıştır. Bu ölçümler sonucunda; en kalın kök boğazı çapına sahip orijin $3.29 \mathrm{~mm}$ ile 4 nolu orijin, en ince çapa sahip orijin ise $2.02 \mathrm{~mm}$ ile 5 nolu orijin olarak belirlenmiştir (Şekil 3). Tüm orijinler bazında ortalama kök boğazı çapı ise $2.6 \mathrm{~mm}$ olarak hesaplanmıştır.

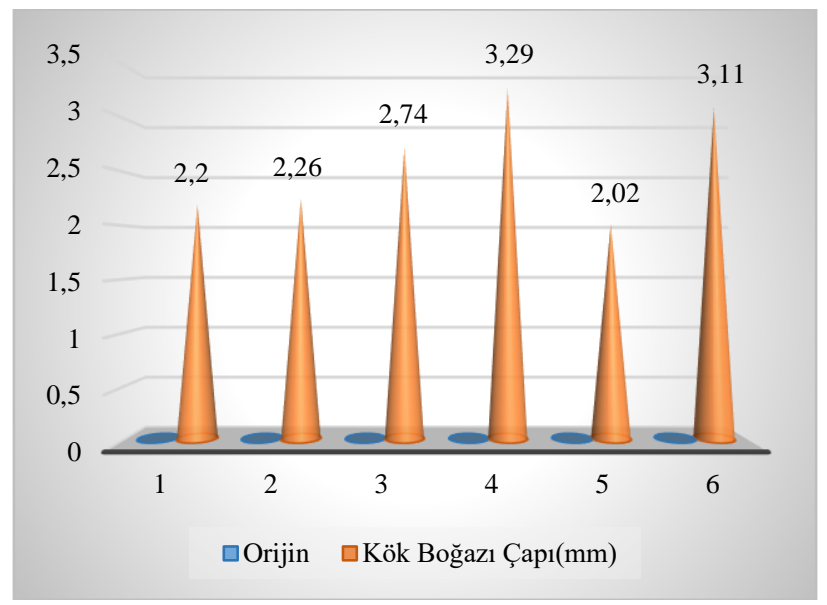

Şekil 3. Orijinlere göre ortalama kök boğazı çapı değişimi
Fidanların tepe sürgün boyu bakımından orijinlerin ortalama değerleri; 1 nolu orijin $2.43 \mathrm{~cm}, 2$ nolu orijin $2.31 \mathrm{~cm}, 3$ nolu orijin $2.46 \mathrm{~cm}, 4$ nolu orijin $4.68 \mathrm{~cm}, 5$ nolu orijin $1.75 \mathrm{~cm}$ ve 6 nolu orijin $4.04 \mathrm{~cm}$ olarak hesaplanmıştır. $\mathrm{Bu}$ ölçümler sonucunda; en uzun boya sahip orijin $4.68 \mathrm{~cm}$ ile 4 nolu orijin, en kisa boya sahip orijin ise $1.75 \mathrm{~cm}$ ile 5 nolu orijin olarak belirlenmiştir (Şekil 4). Orijinlerin ortalama tepe sürgün boyu ise 2.9 cm olarak hesaplanmıştır.

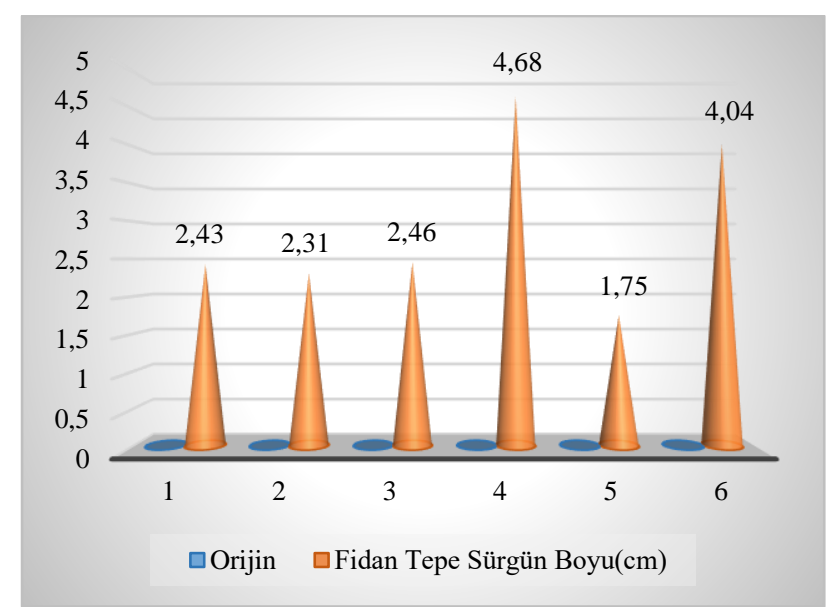

Şekil 4. Orijinlere göre ortalama tepe sürgün boyu değişimi

Fidanların ilk boyu bakımından orijinlerin ortalama değerleri; 1 nolu orijin $1.88 \mathrm{~cm}, 2$ nolu orijin $2.91 \mathrm{~cm}, 3$ nolu orijin $1.15 \mathrm{~cm}, 4$ nolu orijin $1.52 \mathrm{~cm}, 5$ nolu orijin $1.52 \mathrm{~cm}$ ve 6 nolu orijin $0.97 \mathrm{~cm}$ olarak hesaplanmıştır. $\mathrm{Bu}$ ölçümler sonucunda; en uzun ilk boya sahip orijin $2.91 \mathrm{~cm}$ ile 2 nolu orijin, en k1sa ilk boya sahip orijin ise $0.97 \mathrm{~cm}$ ile 6 nolu orijinde elde edilmiştir (Şekil 5). Tüm orijinlerin ortalama ilk boylarının ortalaması ise $1.66 \mathrm{~cm}$ olarak hesaplanmıştır.

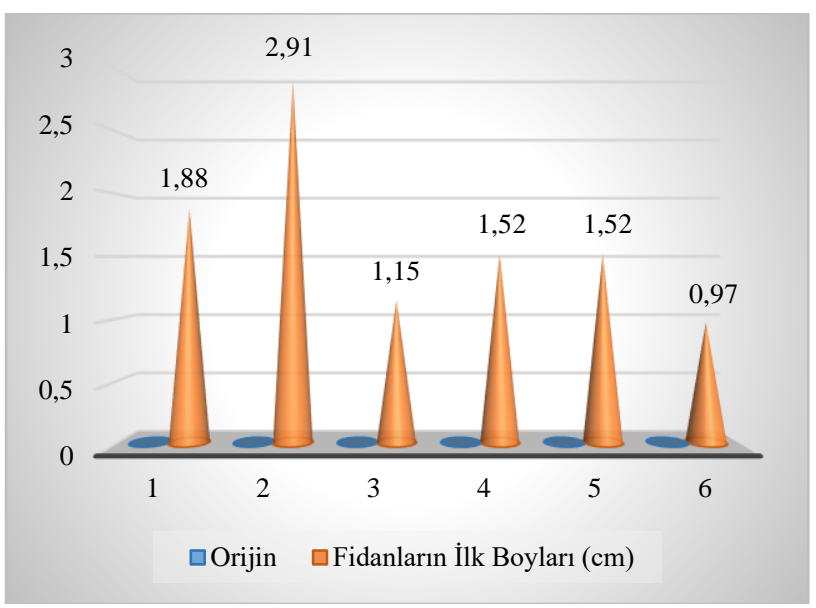

Şekil 5. Orijinlere göre fidanların ortalama tepe tomurcuk sayısı değişimi 
Fidanların tomurcuk sayısı bakımından orijinlerin ortalama değerleri; 1 nolu orijin 0.2 adet, 2 nolu orijin 0.12 adet, 3 nolu orijin 0.8 adet, 4 nolu orijin 2.36 adet, 5 nolu orijin 0.51 adet ve 6 nolu orijin 5.77 adet olarak hesaplanmıştır. Bu ölçümler sonucunda; en çok tomurcuk sayısına sahip orijin 5.77 adet ile 6 nolu orijin, en az tomurcuk sayısına sahip orijin ise 0.12 adet ile 2 nolu orijindir (Şekil 6). Tüm orijinler birlikte değerlendirildiğinde ortalama tomurcuk sayısı 1.63 adet olarak hesaplanmıştır.

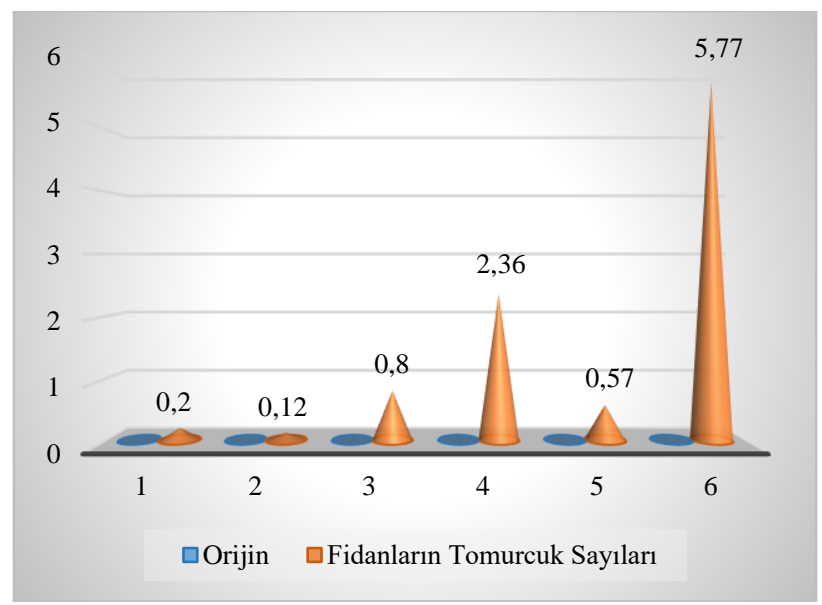

Şekil 6. Orijinlere göre ortalama tomurcuk sayısı değişimi

Fidanların ortalama yan sürgün boyları bakımından orijinlerin ortalama değerleri; 1 nolu orijin $1.20 \mathrm{~cm}, 2$ nolu orijin $1.61 \mathrm{~cm}, 3$ nolu orijin $1.63 \mathrm{~cm}, 4$ nolu orijin $2.04 \mathrm{~cm}, 5$ nolu orijin $1.16 \mathrm{~cm}$ ve 6 nolu orijin $2.03 \mathrm{~cm}$ olarak hesaplanmıştır. Bu ölçümler sonucunda; en uzun ortalama yan sürgün boyuna sahip orijin $2.04 \mathrm{~cm}$ ile 4 nolu orijin, en kısa yan sürgün boyuna sahip orijin ise $1.16 \mathrm{~cm}$ ile 5 nolu orijin olarak belirlenmiştir (Şekil 7). Tüm orijinlerin ortalama yan sürgün boyu ise $1.52 \mathrm{~cm}$ olarak hesaplanmıştır.

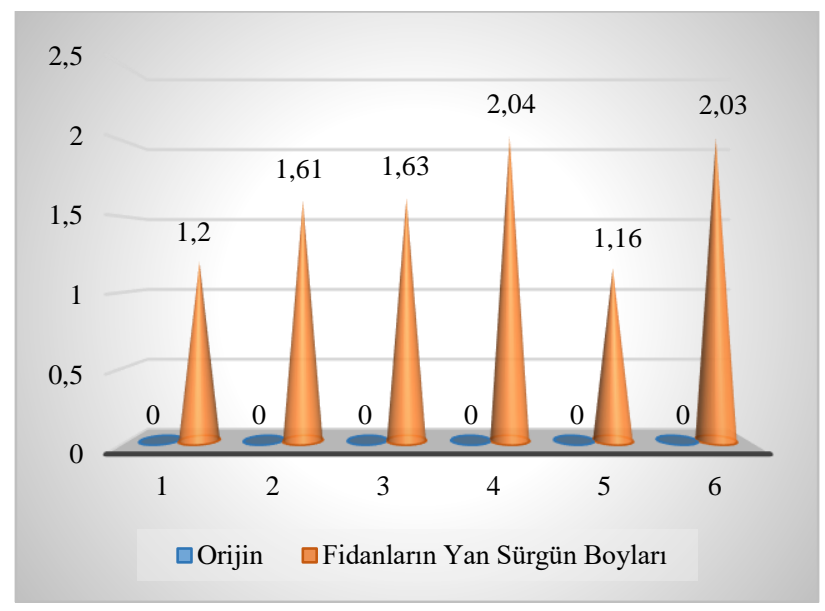

Şekil 7. Orijinlere göre fidanların yan sürgün boylarına ilişkin bulgular
Fidanların ortalama gürbüzlük derecesi bakımından orijinlerin ortalama değerleri; 1 nolu orijin 56.97, 2 nolu orijin 57.84, 3 nolu orijin $45.12,4$ nolu orijin $50.11,5$ nolu orijin 47.15 ve 6 nolu orijin 61.22 olarak hesaplanmıştır. $\mathrm{Bu}$ ölçümler sonucunda; en yüksek gürbüzlük derecesine sahip orijin 61.22 ile 6 nolu orijin, en düşük gürbüzlük derecesine sahip orijin ise 45.12 ile 3 nolu orijin olarak tespit edilmiştir (Şekil 8). Tüm orijinler değerlendirildiğinde $1+0$ yaşındaki kızılçam fidanlarında ortalama gürbüzlük derecesi 53.07 olarak hesaplanmıştır.

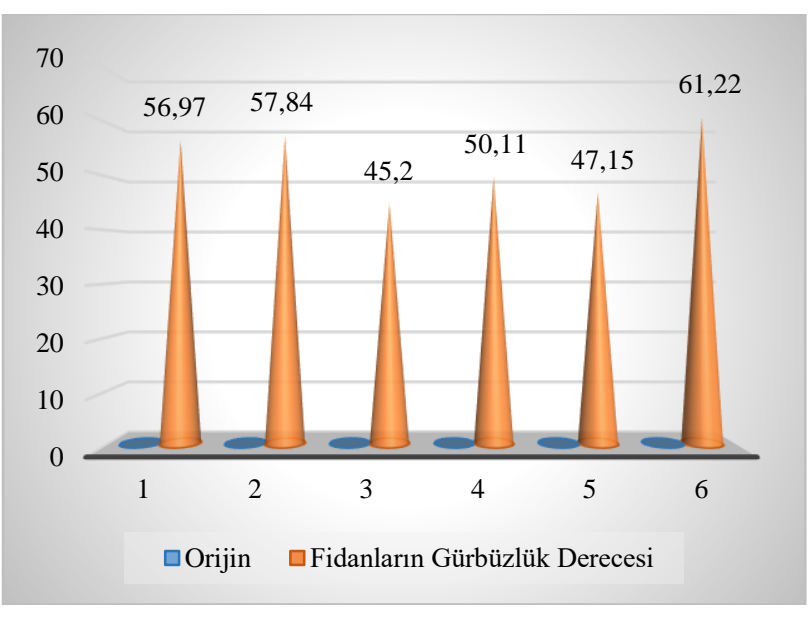

Şekil 8. Orijinlere göre ortalama gürbüzlük derecesi değişimi

Ölçülen morfolojik özelliklere ait normal dağılım testi sonuçları Tablo 2'de verilmiştir. Morfolojik özelliklerin tümü için basıklık ve çarpıklık değerleri -2 ile +2 arasında kaldığından verilerin normal dağılım gösterdiği kabul edilmiştir (Tablo 2).

Normal dağılım gösteren morfolojik özellik verileri için orijinler arasında fark olup olmadığını tespit etmek amaciyla parametrik testlerden One Way-ANOVA testi uygulanmış ve sonuçlar Tablo 3'de gösterilmiştir. Tablo 3 incelendiğinde tüm morfolojik özellikler açısından orijinler arasında $p<0.05$ önem düzeyinde anlamlı farklılıkların olduğu tespit edilmiştir.

Morfolojik özellikler açısından orijinler arasında anlamlı farklılıklar tespit edildiği için homojen grupların $(p<0.05)$ belirlenmesi amaciyla Tukey testi uygulanmıştır. Tukey testi sonuçları Tablo 4'de verilmiştir. Tablo 4 incelendiğinde fidan boyu, kök boğazı çapı ve gürbüzlük derecesi açısından orijinler arasında 4 farklı grup ortaya çıkarken, tepe sürgün boyu, ilk boy, tepe tomurcuk sayısı ve ortalama yan sürgün boyu açısından 3 farklı grup oluşmuştur. Fidan boyu ve gürbüzlük derecesi açısından 6 nolu orijin, kök boğazı çapı ve tepe sürgün boyu için 4 nolu orijin, ilk boy için 2 nolu orijin, tepe tomurcuğu sayısı ve ortalama yan sürgün boyu için 4 ve 6 nolu orijinler en iyi sonuçları vermiştir. 
Tablo 2. Orijinlere ait verilerinin istatiksel sonuçlarının basıklık ve çarpıklık değerleri

\begin{tabular}{ccc}
\hline Değiş̧kenler & $\begin{array}{c}\text { Basılklık } \\
\text { (Kurtosis) }\end{array}$ & $\begin{array}{c}\text { Çlık } \\
\text { (Skewness) }\end{array}$ \\
\hline Fidan boyu & -1159 & 0.338 \\
Kök boğazı çapı & -0.607 & 0.183 \\
Tepe sürgün boyu & -0.724 & 0.230 \\
İlk boy & -1.884 & -0.122 \\
Tomurcuk sayısı & -1.780 & 0.392 \\
Ortalama yan sürgün boyu & -0.407 & 0.279 \\
Gürbüzlük derecesi & -1.758 & 0.311 \\
\hline
\end{tabular}

Tablo 3. Morfolojik özelliklere ait varyans analizi sonuçları

\begin{tabular}{ccc}
\hline Değişkenler & F değeri & $\begin{array}{c}\text { Onem düzeyi } \\
(p<0.05)\end{array}$ \\
\hline Fidan boyu & 167.038 & 0.000 \\
Kök boğazı çapı & 129.724 & 0.000 \\
Tepe sürgün boyu & 148.010 & 0.000 \\
İlk boy & 15.328 & 0.000 \\
Tomurcuk sayısı & 47.408 & 0.000 \\
Ortalama yan sürgün boyu & 72.962 & 0.000 \\
Gürbüzlük derecesi & 156.438 & 0.000 \\
\hline
\end{tabular}

Tablo 4. Tukey testi sonucu morfolojik özelliklere bağlı homojen grupların dağılımı

\begin{tabular}{|c|c|c|c|c|c|c|c|}
\hline Orijin & $\begin{array}{l}\text { Fidan boyu } \\
(\mathrm{cm})\end{array}$ & $\begin{array}{c}\text { Kök boğazı çapı } \\
(\mathrm{mm})\end{array}$ & $\begin{array}{c}\text { Tepe sürgün } \\
\text { boyu } \\
(\mathrm{cm})\end{array}$ & $\begin{array}{l}\text { İlk boy } \\
(\mathrm{cm})\end{array}$ & $\begin{array}{c}\text { Tomurcuk } \\
\text { sayıs1 } \\
(\mathrm{N}) \\
\end{array}$ & $\begin{array}{c}\text { Ortalama yan } \\
\text { sürgün boyu } \\
(\mathrm{cm})\end{array}$ & $\begin{array}{c}\text { Gürbüzlük } \\
\text { derecesi }\end{array}$ \\
\hline 1 & $12.48(\mathrm{C})^{*}$ & 2.21 (D) & $2.43(\mathrm{C})$ & $1.89(\mathrm{~B})$ & $1.61(\mathrm{C})$ & $1.20(\mathrm{C})$ & $56.97(\mathrm{~B})$ \\
\hline 2 & $12.43(\mathrm{C})$ & 2.26 (D) & $2.31(\mathrm{C})$ & $2.93(\mathrm{~A})$ & $0.99(\mathrm{C})$ & $1.61(\mathrm{~B})$ & $57.84(\mathrm{~B})$ \\
\hline 3 & $12.43(\mathrm{C})$ & $2.78(\mathrm{C})$ & $2.46(\mathrm{C})$ & $1.15(\mathrm{C})$ & $1.92(\mathrm{~B})$ & $1.63(\mathrm{~B})$ & 45.12 (D) \\
\hline 4 & 16.57 (B) & $3.31(\mathrm{~A})$ & $4.68(\mathrm{~A})$ & $1.53(\mathrm{~B})$ & $3.68(\mathrm{~A})$ & $2.04(\mathrm{~A})$ & $50.11(\mathrm{C})$ \\
\hline 5 & 9.65 (D) & 2.09 (D) & 1.75 (D) & $1.52(\mathrm{~B})$ & $1.58(\mathrm{C})$ & $1.16(\mathrm{C})$ & 47.15 (D) \\
\hline 6 & $18.87(\mathrm{~A})$ & $3.11(\mathrm{~B})$ & $4.04(\mathrm{~B})$ & $0.97(\mathrm{C})$ & $3.08(\mathrm{~A})$ & $2.03(\mathrm{~A})$ & $61.22(\mathrm{~A})$ \\
\hline
\end{tabular}

*; Aynı harfler benzer grupları göstermektedir.

Elde edilen verilerden SPSS istatistik paket programında ortalama değerler belirlenmiş ve fidanların halen yürürlükte bulunan TS 2265/Şubat 1988 kalite sınıflarına dağılımı (Tablo 5) kullanılarak çalışmada kullanılan 1+0 yaşlı kızılçam fidanlarının fidan kalite sınıflarına dağılımı orijinler bazında belirlenmiştir.

Fidan boyuna göre kalite sinıflandırması yapıldı̆̆ında sadece 5 nolu orijinin elverişsiz kalite sınıfında yer aldığ diğer orijinlerin ise I. Kalite sınıfinda olduğu tespit edilmiştir. Kök boğazı çapına göre fidan kalite sınıflandırma yapıldığında tüm orijinlerin I. kalite sınıfında yer aldıkları belirlenmiştir. Fidan boyu + kök boğazı çap1 değerleri dikkate alınarak yapılan kalite sınıflandırmasında ise 5 nolu orijinin elverişsiz kalite sınıfında yer aldığı diğer orijinlerin ise I. Kalite sınıfında olduğu tespit edilmiştir (Tablo 6).

Halen yürürlükte bulunan TS 2265/Şubat 1988 kalite sınıflarına göre orijin bazında kalite sınıflarına bağlı olarak ölçüm yapılan fidan sayılarının dağılımları ve fidan yüzdeleri Tablo 7'de verilmiştir.

Tablo 5. 1+0 yaşlı Kızılçama ait kalite sınıfları (Anonim 1988)

\begin{tabular}{cccc}
\hline Kalite sınıfi & $\begin{array}{c}\text { Fidan boyu }(\mathrm{FB}) \\
(\mathrm{cm})\end{array}$ & $\begin{array}{c}\text { Kök boğazı çapı }(\mathrm{KBÇ}) \\
(\mathrm{mm})\end{array}$ & Fidan boyu + Kök boğazı çapı \\
\hline I & $12 \leq$ & $2 \leq$ & $12 \leq \mathrm{FB}+2 \leq \mathrm{KBÇ}$ \\
II & $12>\mathrm{FB} \leq 10$ & - & $12>\mathrm{FB} \leq 10+2 \leq \mathrm{KBC}$ \\
Elverişşiz & $10>$ & $2>$ & $10>\mathrm{FB}+2>\mathrm{KBC}$ \\
\hline
\end{tabular}

Tablo 6. $1+0$ yaşlı kızılçamda fidan kalite sınıflandırması ilişkin ortalama değerler

\begin{tabular}{ccccccc}
\hline \multirow{2}{*}{ Orijin } & $\begin{array}{c}\text { Ortalama FB } \\
(\mathrm{cm})\end{array}$ & FB kalite sınıfi & $\begin{array}{c}\text { Ortalama KBÇ } \\
(\mathrm{mm})\end{array}$ & $\begin{array}{c}\text { KBÇ kalite } \\
\text { sinıfi }\end{array}$ & $\begin{array}{c}\text { Ortalama } \\
\text { FB+KBÇ }\end{array}$ & $\begin{array}{c}\text { FB+KBÇ kalite } \\
\text { sınıfi }\end{array}$ \\
\hline 1 & 12.5 & $\mathrm{I}$ & 2.20 & $\mathrm{I}$ & 12.72 & $\mathrm{I}$ \\
2 & 13.0 & $\mathrm{I}$ & 2.26 & $\mathrm{I}$ & 13.23 & $\mathrm{I}$ \\
3 & 12.4 & $\mathrm{I}$ & 2.74 & $\mathrm{I}$ & 12.67 & $\mathrm{I}$ \\
4 & 16.6 & $\mathrm{I}$ & 3.29 & $\mathrm{I}$ & 16.93 & $\mathrm{I}$ \\
5 & 9.70 & Elverişsiz & 2.02 & $\mathrm{I}$ & 9.70 & Elverişsiz \\
6 & 18.9 & I & 3.11 & $\mathrm{I}$ & 19.11 & $\mathrm{I}$ \\
\hline
\end{tabular}


Tablo 7. KBÇ ve FB'na göre kalite sınıflandırmasının orjinlere göre dağılımı

\begin{tabular}{|c|c|c|c|c|c|c|c|c|c|c|c|}
\hline \multirow{3}{*}{ Orijin } & \multirow{3}{*}{$\begin{array}{l}\text { Fidan } \\
\text { say1s1 }\end{array}$} & \multicolumn{6}{|c|}{ Fidan boyuna göre kalite Sınıfları } & \multicolumn{4}{|c|}{ KBC'ye göre kalite sinıfları } \\
\hline & & \multicolumn{2}{|c|}{ I } & \multicolumn{2}{|c|}{ II } & \multicolumn{2}{|c|}{ Elverișsiz } & \multicolumn{2}{|c|}{ I } & \multicolumn{2}{|c|}{ Elverișsiz } \\
\hline & & FS & $\%$ & FS & $\%$ & FS & $\%$ & FS & $\%$ & FS & $\%$ \\
\hline 1 & 300 & 157 & 52.3 & 42 & 14.0 & 101 & 33.7 & 185 & 61.7 & 115 & 38.3 \\
\hline 2 & 300 & 196 & 65.3 & 77 & 25.7 & 27 & 9.0 & 247 & 82.3 & 53 & 17.7 \\
\hline 3 & 300 & 152 & 52.7 & 73 & 24.3 & 75 & 25.0 & 277 & 92.3 & 23 & 7.7 \\
\hline 4 & 300 & 225 & 75.0 & 48 & 16.0 & 27 & 9.0 & 287 & 95.7 & 13 & 4.3 \\
\hline 5 & 300 & 35 & 11.7 & 78 & 26.0 & 187 & 62.3 & 164 & 54.7 & 136 & 45.3 \\
\hline 6 & 300 & 286 & 95.3 & 14 & 4.7 & 0 & 0.0 & 284 & 94.7 & 16 & 5.3 \\
\hline
\end{tabular}

1 nolu orijinde fidan boyuna göre I. kalite sınıfında yer alan fidan sayıs 157 adet (\%52.3) iken, II. Kalite sinıfinda yer alan fidan sayısı 42 adet (\%14) ve elverişsiz sinifda yer alan fidan say1s1 101 adettir (\%33.7). 2 nolu orijinde I. kalite sinıfinda yer alan fidan sayısı 196 adet (\%65.3), II. kalite sinıfinda yer alan fidan sayısı 77 adet (\%25.7) ve elverişsiz sinıfta yer alan fidan sayısı 27 adettir (\%9). 3 nolu orijinde I. kalite sinıfinda yer alan fidan sayısı 152 adet (\%52.7), II. kalite sınıfında yer alan fidan sayısı 73 adet (\%24.3) ve elverişsiz sinıfta yer alan fidan sayıs 75 adettir (\%25). 4 nolu orijinde I. kalite sinifinda yer alan fidan sayısı 225 adet (\%75), II. kalite sınıfinda yer alan fidan sayısı 48 adet (\%16) ve elverişsiz sinifta yer alan fidan sayıs 27 adettir (\%9). 5 nolu orijinde I. kalite sinıfinda yer alan fidan sayısı 35 adet (\%11.7), II. kalite sinıfinda yer alan fidan sayıs1 78 adet (\%26) ve elverişsiz sinıfta yer alan fidan sayısı 187 adettir (\%62.3). 6 nolu orijinde I. kalite sinifinda yer alan fidan sayısı 286 adet (\%95.3), II. kalite sinıfinda yer alan fidan sayısı 14 adet (\%4.7) ve elverişsiz sınıfta yer alan fidan sayısı bulunmamaktadır (Tablo 7).

1 nolu orijinde fidan kök boğazı çapına (KBÇ) göre I. kalite sinıfinda yer alan fidan sayısı 185 adet (\%61.7) ve elverişsiz sinıfta yer alan fidan sayısı 115 adettir (\%38.3). 2 nolu orijinde I. kalite sinıfında yer alan fidan sayıs 247 adet (\%82.3) ve elverişsiz sinıfta yer alan fidan sayıs1 53 adettir (\%17.7). 3 nolu orijinde I. kalite sinıfinda yer alan fidan sayısı 277 adet (\%92.3) ve elverişsiz sınıfta yer alan fidan sayısı 23 adettir (\%7.7). 4 nolu orijinde I. kalite sinıfinda yer alan fidan sayıs 287 adet (\%95.7) ve elverişsiz sinıfta yer alan fidan sayısı 13 adettir (\%4.3). 5 nolu orijinde I. kalite sinıfinda yer alan fidan sayısı 164 adet (\%54.7) ve elverişsiz sinıfta yer alan fidan sayısı 136 adettir (\%45.3). 6 nolu orijinde I. kalite sinıfinda yer alan fidan sayısı 284 adet (\%94.7) ve elverişsiz sınıfta yer alan fidan sayısı 16 adettir (\%5.3) (Tablo 7).

Çalışma kapsamında kızılçam fidanlarında ölçülen tüm morfolojik özelliklere ilişkin orijinler arasında meydana gelen gruplar hiyerarşik kümeleme analizi ile belirlenmiştir. $\mathrm{Bu}$ gruplandırmaların anlamlılığg ise ayırma analizi (discriminant) ile test edilmiştir. Kümeleme analizi ile meydana gelen gruplandırmalar Şekil 9'da gösterilmiştir. Hiyerarşik kümeleme analizi ile orijinler arasında meydana gelen grupların, ayırma analizi sonucunda iki gruba ayrım için önem düzeyi 0.05 'ten küçük çıkmış olup ikiden fazla gruplandırma anlamsız bulunmuştur. Buna göre 1, 2, 3 ve 5 nolu orijinler ilk grubu oluştururken, 4 ve 6 nolu orijinler ikinci grupta yer almıştır.

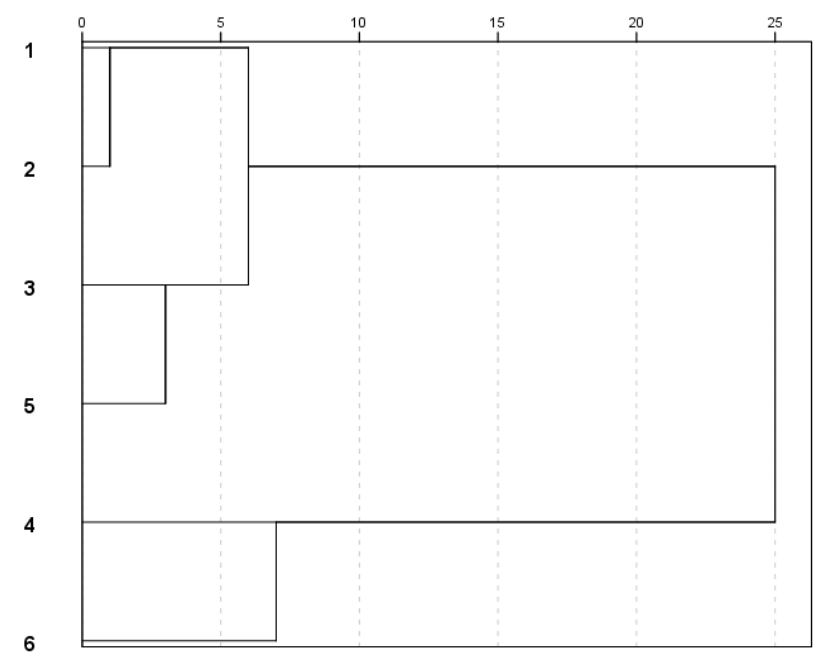

Şekil 9. Hiyerarşik kümeleme analizi sonucunda populasyonların ölçülen morfolojik özelliklere göre meydana getirdiği gruplar

\section{Sonuçlar ve tartıșma}

Fidanların boyu bakımından orijinlerin ortalama değerleri; 1 nolu orijin $12.5 \mathrm{~cm}, 2$ nolu orijin $13.0 \mathrm{~cm}, 3$ nolu orijin $12.4 \mathrm{~cm}, 4$ nolu orijin $16.6 \mathrm{~cm}, 5$ nolu orijin $9.7 \mathrm{~cm}$ ve 6 nolu orijin $18.9 \mathrm{~cm}$ olarak hesaplanmıştır. Tüm orijinler bazında genel değerlendirme yapıldığında ise ortalama fidan boyu $13.8 \mathrm{~cm}$ olarak hesaplanmıştır. Fidan boyu açısından fidan kalite sınıfları değerlendirildiğinde ise 5 nolu orijin haricindeki orijinlerin I. Kalite sınıfında yer aldığı görülmüştür. Benzer durum $\mathrm{FB}+\mathrm{KBÇ}$ kriterine göre yapılan kalite sınıflandırmasında da görülmektedir. Diğer taraftan, 1 nolu orijin için ölçüme konu olan 300 adet fidanın 157 adedi (\%52.3) 1.sinifta, 42 adedi (\%14) 2. sinifta ve 101 adedi (\%33.7) elverişsiz sınıfta yer almaktadır. 2 nolu orijin için ölçüme konu olan 300 adet fidanın 196 adedi (\%65.3) 1. sinifta, 77 adedi (\%25.7) 2. sinıfta ve 27 adedi (\%9) elverişsiz sınıfta yer almaktadır. 3 nolu orijin için ölçüme konu olan 300 adet fidanın 152 adedi (\%52.7) 1 . sinıfta, 73 adedi (\%24.3) 2. sinıfta ve 75 adedi (\%25) elverişsiz sınıfta yer almaktadır. 4 nolu orijin için ölçüme konu olan 300 adet fidanın 225 adedi (\%75) fidan 1 . sınıfta, 48 adedi (\%16) 2. sinıfta ve 27 adedi (\%9) elverişsiz sınıfta yer almaktadır. 5 nolu orijin için ölçüme konu olan 300 adet fidanın 35 adedi (\%11.7) 1. sinıfta, 78 adedi (\%26) 2. sinıfta ve 187 adedi (\%62.3) elverişsiz sınıfta yer almaktadır. 6 nolu orijin için ölçüme konu 
olan 300 adet fidanın 286 adedi (\%95.3) 1.sinıfta, 14 adedi (\%4.7) 2. sınıfta yer almaktadır. Dolayısıyla ölçüm yapılan fidanların fidan boyu açısından \%100 oranında I. kalite sınıfında yer aldığı orijin çalışma kapsamında elde edilememiştir.

Fidanların kök boğazı çapı bakımından orijinlerin ortalama değerleri; 1 nolu orijin $2.2 \mathrm{~mm}, 2$ nolu orijin $2.26 \mathrm{~mm}, 3$ nolu orijin $2.74 \mathrm{~mm}, 4$ nolu orijin $3.29 \mathrm{~mm}, 5$ nolu orijin $2.02 \mathrm{~mm}$ ve 6 nolu orijin $3.11 \mathrm{~mm}$ olarak hesaplanmıştır. Bu ölçümler sonucunda; en kalın kök boğazı çapına sahip orijin $3.29 \mathrm{~mm}$ ile 4 nolu orijin, en ince çapa sahip orijin ise $2.02 \mathrm{~mm}$ ile 5 nolu orijin olarak belirlenmiştir. Tüm orijinler bazında ortalama kök boğazı çapı ise $2.6 \mathrm{~mm}$ olarak hesaplanmıştır. Halen, yürürlükte bulunan TS 2265/Şubat 1988 (Anonim, 1988) kalite sınıflandırmasına göre $1+0$ yaşlı kızılçam fidanları için kök boğazı çaplarının 3 mm'nin üzerinde olması tavsiye edilmiştir. Bu bağlamda çalışma kapsamında sadece 4 ve 6 nolu orijinler kaliteli olarak nitelendirebilir. Orijinler bazında kök boğazı çapı değerleri açısından istatistiksel olarak anlamlı farklılıklar bulunmakla birlikte genel ortalama kök boğazı çapı değeri dikkate alındığında kaliteli bir fidan gelişiminin olduğunu söyleyebilmek de mümkündür. Diğer taraftan, 1 nolu orijin için ölçüme konu olan 300 adet fidanın 185 adedi (\%61.7) 1. sinıfta ve 115 adedi (\%38.3) elverişsiz sınıfta yer almaktadır. 2 nolu orijin için ölçüme konu olan 300 adet fidanın 247 adedi (\%82.3) 1. sınıfta ve 53 adedi (\%17.7) elverişsiz sınıfta yer almaktadır. 3 nolu orijin için ölçüme konu olan 300 adet fidanın 277 adedi (\%92.3) 1. sinifta ve 23 adedi (\%7.7) elverişsiz sınıfta yer almaktadır. 4 nolu orijin için ölçüme konu olan 300 adet fidanın 287 adedi (\%95.7) 1. sinıfta ve 13 adedi (\%4.3) elverişsiz sınıfta yer almaktadır. 5 nolu orijin için ölçüme konu olan 300 adet fidanın 164 adedi (\%54.7) 1. sinıfta ve 136 adedi (\%45.3) elverişsiz sınıfta yer almaktadır. 6 nolu orijin için ölçüme konu olan 300 adet fidanın 284 adedi (\%94.7) fidan 1. sınıfta ve 16 adedi (\%5.3) elverişsiz sinıfta yer almaktadır.

Bilir (2019) yapmış olduğu çalışmada, 1+0 yaşlı çıplak köklü kızılçam fidanlarında ortalama boyun $8.20 \mathrm{~cm}$ ve kök boğazı çapının 3.97 mm olduğunu ifade etmektedir. Dilaver vd. (2015), 1+0 yaşlı çıplak köklü ve tüplü Kızılçam fidanlarında yapmış oldukları çalışmada, ortalama fidan boyunun $12.5 \mathrm{~cm}$, kök boğazı çapının ise $2.74 \mathrm{~mm}$ olduğunu belirtmişlerdir. Özel vd. (2018), kızılçamda ortalama fidan boyunun fidan materyalinin tipine bağlı olarak $5.7 \mathrm{~cm}$ ile $21.4 \mathrm{~cm}$ arasında değiştiğini, kök boğazı çapının ise $1.5 \mathrm{~mm}$ ile $4.4 \mathrm{~mm}$ arasında değiştiğini ifade etmektedir. Ölmez ve Ateş Göksu (2018) kızılçamda fidan boyu bakımından en iyi fidan boyunun $7.5 \mathrm{~cm}$ aralıklarla seyreltme yapilan fidanlarda, en düşük fidan boyunun ise $2.5 \mathrm{~cm}$ aralıklarla yetiştirilen fidanlarda elde edildiğini belirtmiştir. Bununla birlikte türün gerek $1+0$ yaşlı çıplak köklü ve gerekse 1+1 yaşlı tüplü fidanlarında, boy ve kök boğazı çapı değerleri açısında oldukça geniş bir varyasyonun olduğu da yapılan çalışmalarda belirtilmektedir (Üçler vd. 2000; Dilaver vd. 2015; Y1lmazer ve Bilir 2016; Bilir 2019). Bu bağlamda çalışma kapsamında elde edilen veriler ile literatür arasında oldukça benzer sonuçların olduğunu ifade etmek de mümkündür.

Fidanların ortalama yan sürgün boyları bakımından orijinlerin ortalama değerlerine göre bakıldığında en uzun yan sürgün boya sahip orijin $2.04 \mathrm{~cm}$ ile 4 nolu orijin, en kısa yan sürgün boya sahip orijin ise $1.16 \mathrm{~cm}$ ile 5 nolu orijinde elde edilmiştir. Orijinlerin yan sürgün boylarının ortalaması ise $1.52 \mathrm{~cm}$ olarak hesaplanmıştır. Yan sürgünlerin ortalama boyları dikkate alındığında orijinler arasındaki farklılıklar kök boğazı çapı ve fidan boyu değerlerinin kıyaslanması ile elde edilen kalite sınıflandırmasındaki sonuçlara benzer durumları ortaya çıkarmaktadır. Bu durum, fidan boyu ve kök boğazı çapı değerlendirmesiyle birlikte ortalama yan sürgün boyu değerlendirmelerinin de kalite sinıflandırılmasında kullanılabilme olasılığını güçlendirmektedir.

Fidanların ortalama gürbüzlük derecesi bakımından orijinlerin ortalama değerleri;

1 nolu orijin 56.97, 2 nolu orijin $57.84,3$ nolu orijin 45.12, 4 nolu orijin 50.11, 5 nolu orijin 47.15 ve 6 nolu orijin 61.22 olarak hesaplanmıştır. $\mathrm{Bu}$ ölçümler sonucunda; en yüksek gürbüzlük derecesine sahip orijin 61.22 ile 6 nolu orijin, en düşük gürbüzlük derecesine sahip orijin ise 45.12 ile 3 nolu orijin olarak tespit edilmiştir. Tüm orijinler değerlendirildiğinde $1+0$ yaşındaki kızılçam fidanlarında ortalama gürbüzlük derecesi 53.07 olarak hesaplanmıştır.

Fidanların tepe tomurcuk sayıları dikkate alındığında, en fazla tepe tomurcuk sayısına sahip orijin 5.77 adet ile 6 nolu orijin, en az tepe tomurcuk sayısina sahip orijin ise 0,12 adet ile 2 nolu orijin olarak hesaplanmıştır. Tepe tomurcuk sayısı fazla olan orijinlerin gürbüzlük derecesinin de yüksek olduğu tespit edilmiştir. Dolayısıyla, tepe tomurcuk sayısının miktarının fidanın kalitesi hakkında ön değerlendirmelerde kullanılabileceğini ifade etmek mümkündür.

Fidanların ilk boyu bakımından orijinlerin ortalama değerleri; 1 nolu orijin $1.88 \mathrm{~cm}, 2$ nolu orijin $2.91 \mathrm{~cm}, 3$ nolu orijin $1.15 \mathrm{~cm}, 4$ nolu orijin $1.52 \mathrm{~cm}, 5$ nolu orijin $1.52 \mathrm{~cm}$ ve 6 nolu orijin $0.97 \mathrm{~cm}$ olarak hesaplanmıştır. Tüm orijinlerin ilk boylarının ortalaması ise $1.66 \mathrm{~cm}$ olarak hesaplanmıştır. Başta fidan boyu, kök boğazı çapı, gürbüzlük derecesi, tepe tomurcuğu sayısı olmak üzere birçok morfolojik özellik açısından ön sıralara geçen 6 nolu orijin, diğer taraftan en kisa ilk boya sahip orijin olarak belirlenmiştir. Bu durum fidan kalitesi ile ilk boy arasında negatif bir ilişkinin olduğu şeklinde yorumlanabilir.

Farklı orijinlerden toplanan tohumlardan elde edilen fidanların morfolojik özellikleri açısından anlamlı farklılıklar göstermesi, bu farklılıklara bağlı olarak ortaya çıkan kalite sınıflandırması farklılıkları kitlesel fidan üretiminde tohum kaynağının önemini ortaya koymaktadır. Çalışma kapsamında elde edilen hiyerarşik kümeleme analizi sonucunda meydana gelen gruplandırmada orijinlerin yetişme ortamı özellikleri ve yükselti farklılıkların etkili olduğu düşünülmektedir. Bilir vd (2010) ve fistık çamında yaptıkları çalışmada sınırlı sayıda ailede çalışma yapmalarına rağmen aileler arasında geniş farklılıkların olduğunu belirledikleri 
çalıșmada tohum hasadında bireysel seleksiyonun kitlesel seleksiyondan daha önemli olduğunu ifade etmişlerdir. Cedrus libani (Bilir 1997) ve Pinus sylvestris (Ulusan ve Bilir 2008) gibi farklı orman ağacı türleri için fidan morfolojisinde orijinler arasında büyük farklılıkların olduğu ifade edilmiştir.Yükselti kuşaklarına bağlı olarak gerçekleştirilen kızılçam orijin-döl denemelerinde orijin ve aile düzeyinde önemli büyüme ve gelişme farklıkları belirlenmiştir (Işık vd. 1987; Işık 1998; Işık vd. 1999). Işık ve Işık (1999) kızılçamda gözlemledikleri dal ve tepe tacı varyasyonlarının büyük bir kısmının orijinler arasındaki genetik varyasyonlardan kaynaklandığını ifade etmektedir. Işık vd. (2001), orta yükselti kuşağında yer alan orijinden elde ettikleri fidanların alçak ve yüksek zona göre çok daha fazla boy büyümesi yaptığını ifade etmiştir. Çalışma kapsamında fidan boyu açısından kalite siniflandırmasında 800-1200 metre yükselti kuşağında yer alan 5 nolu orijinin $0-400$ ve 400-800 metre yükselti kuşaklarında yer alan diğer orijinlere göre elverişsiz kalite sınıfında yer alması bu bağlamda kızılçamda yüksek yükselti kuşağının fidan üretimi noktasında ağaçlandırma sahası yükselti kuşaklarına göre değerlendirmeye alınması gerektiği sonucunu desteklemektedir.

Ağaçlandırma çalışmalarının hem ekonomik (fidan masrafı gibi) hem de biyolojik başarısı (yaşama yüzdesi, adaptasyon yeteneği gibi) için fidan özellikleri, tohum kaynağı ve bunların varyasyonu önemli bir rol oynamaktadır (Yücedağ vd., 2010). Kaliteli fidan yetiştirmenin ağaçlandırma çalışmalarındaki maliyetleri ne kadar düşüreceği şüphesiz ağaçlandırma sahalarındaki fidan gelişimleriyle ortaya çıkacak bir bulgu olsa da gerek boy gelişimi gerekse de kök boğazı çap1 gelişimiyle ön plana çıkan fertlerin ait oldukları orijinler, yaşama gücü ve diri örtü mücadelesi ile ilgili avantajlı bir durumu yakalayacak kültürlerin elde edilmesinde kullanılmalıdır yaklaşımı yanıltıcı olmayacaktır.

\section{5. Öneriler}

Kızılçamda morfolojik varyasyonlarla ilgili literatür sonuçları ve bu çalışma kapsamında elde edilen sonuçlar tohum kaynağına bağlı olarak farklı varyasyonların ortaya çıktığını göstermektedir. Ancak fidan kalitesini etkileyen birçok çevre ve genetik faktörün olduğu değerlendirildiğinde fidan kalite sınıflandırmasında fidan boyu ve kök boğazı çapı değerlendirmesinin yeterli olmayacağı sonucunu doğurmaktadır. Bu bağlamda Türk Standartları Enstitüsü kalite sınıflandırmasında türlere bağlı olarak yaş, fidan tipi ile tohum kaynağı ve bölgesel bazlı yeni kalite sınıflarının hazırlanmasının önemli olduğunu ifade etmek gerekir. Bu bağlamda, özellikle hiyerarşik kümeleme analizi sonuçlarına göre ölçülen tüm morfolojik özellikler açısından aynı grupta yer alan 4 ve 6 nolu orijinlerin, ortalama yan sürgün boyu ve ortalama tomurcuk sayısı değerleri açısından da istatistiksel olarak aynı grup içerisinde yar almaları fidan kalite sınıflandırmasında fidan boyu ve kök boğazı çapı ile birlikte tomurcuk sayısı ve yan sürgün boyu kriterlerinin de ilk değerlendirmelere konu edilmesinin uygun olabileceği önerilebilir. Fidanlık ortamında seyreltmenin yapılmadığ 1 , yapılması halinde ise morfolojik özelliklerde pozitif bazı değişikliklerin oluşabileceğini düşündürmektedir. Dolayısıyla, fidan üretimi çalışmalarında kaliteli fidan üretimi açısından kültür bakımı işlemlerinin mutlak suretle geciktirilmeden yapılması gerekmektedir.

\section{Teşekkür}

Bu çalışma Karadeniz Teknik Üniversitesi Fen Bilimleri Enstitüsü Orman Mühendisliği Anabilim Dalında hazırlanan yüksek lisans tezi verileri kullanılarak hazırlanmıştır.

\section{Kaynaklar}

Anonim (1988). İğne yapraklı ağaç fidanları, TS 2265/Şubat-1988. Türk Standartları Enstitüsü Yayınları, Ankara.

Anonim (2005). Ecosystems and human well-being: biodiversity synthesis. Millennium Ecosystem Assessment ,World Resources Institute, Washington DC.

Anonim (2020). Orman Genel Müdürlüğü Faaliyet Raporu 2020. T.C. Tarım ve Orman Bakanlığı, Ankara

Bilir N (1997). Doğu Karadeniz Bölgesinde Toros sediri (Cedrus libani A. Rich) orijin denemeleri fidanlık aşaması. Yüksek Lisans Tezi, KTÜ Fen Bilimleri Enstitüsü, Trabzon.

Bilir N(2019). Kızılçam'da (Pinus brutia Ten.) fidan kalitesi. Mehmet Akif Ersoy Üniversitesi Fen Bilimleri Enstitüsü Dergisi, 10(1):95101.

Bilir N, Kaya C, Ulusan M.D (2010). Aydın orijinli fıstıkçamı (Pinus pinea L.) fidanlarında morfolojik özellikler ve fidan kalitesi. Kastamonu Üniversitesi Orman Fakültesi Dergisi, 10(1):37-43.

Boydak M, Dirik H, Çalıkoğlu M (2006). Kızılçam (Pinus brutia Ten.)'ın biyolojisi ve silvikültürü, OGEM-VAK. yayınları, Ankara.

Boydak M, Çalışkan S (2014). Ağaçlandırma. OGEM-VAK, CTA Tanıtım Rek. Hiz. Org. Basın Yayın Bil. San. ve Tic. Ltd. Şti., İstanbul.

Çoşgun S, Şahin M, Özkurt N, Parlak S (2008). Kızılçam (Pinus brutia Ten.) fidanlarında kalite sınıflarının belirlenmesi. T.C. Çevre ve Orman Bakanlığı Batı Akdeniz Ormancılık Araştırma Müdürlüğü Teknik Bülten No: 29, Antalya.

Deligöz A, Genç M, Özçelik H (2009). Kalite sınıflamasının Anadolu karaçamı [Pinus nigra Arn. subsp. pallasiana (Lamb.) Holmboe] fidanlarının arazi performansına etkisi. Süleyman demirel Üniversitesi Orman Fakültesi Dergisi, A(2):37-50.

Dilaver M, Seyedi N, Bilir N (2015). Seedling quality and morphology in seed sources and seedling type of brutian pine (Pinus brutia Ten.). World Journal of Agri-cultural Research, 3 (2):83-85.

Dutkuner İ, Bilir N (2011). Clonal repeatability for some seedling characters in Stone pine (Pinus pinea L.). Fresenius Environmental Bulletin, 20:484-488.

George D, Mallery M (2010). SPSS for windows step by step: A simple guide and reference, 17.00 update (10a ed.) Boston: Pearson.

Işık K, Topak M, Keskin A.C (1987). Kızılçamda (Pinus brutia Ten.) orijin denemeleri. Orman Ağaçları ve Tohumları Islah Enst. Yayın No. 3.

Işık F (1998). Kızılçamda (Pinus brutia Ten.) genetik çeşitlilik, kalıtım dereceleri ve genetik kazancın belirlenmesi. Batı Akdeniz Ormancılık Araştırma Enstitüsü Teknik Bülten No.7, Antalya.

Işık F, Işık K, Lee S.L (1999). Genetic variation in Pinus brutia in Turkey: Growth biomass and stem quality traits. Forest Genetics, 6(2):89-99.

Işık K, Işık F (1999). Genetic variation in Pinus brutia in Turkey: Branching and crown traits. Silvae Genetica, 48:293-302.

Işık F, Keskin S, Cengiz Y, Genç A, Doğan B, Tosun S, Özpay Z, Uğurlu S, Örtel E, Dağdaş S, Karatay H, Yoldağ İ (2001). Kızılçam orijin denemelerinin 10 yıllık sonuçları (orijin-çevre etkileşimi ve tohum transferi üzerine etkisi). Batı Akdeniz Ormancılık Araştırma Müdürlüğü Teknik Bülten No:14, Yayın No:158/16, Antalya. 
Lindner M, Maroschek M, Netherer S, Kremer A, Barbati A, GarciaGonzalo J, Seidl R, Delzon S, Corona P, Kolstrom M, Lexer M.J, Marchetti M (2010). Climate change impacts, adaptive capacity, and vulnerability of European forest ecosystems. For. Ecol. Manag., 259(4):698-709.

Ölmez Z, Ateş Göksu T (2018). Yetişme sıklığının Kızılçam (Pinus brutia Ten.) fidanlarının bazı morfolojik kalite kriterleri üzerine etkisi. Ziraat, Orman ve $\mathrm{Su}$ Ürünleri Alanında Yenilikçi Yaklaşımlar, Gece Akademi, Bölüm 15, s.177-199.

Özel H.B, Yücedağ C, Bilir N, Ölmez Z, Aydınhan V(2018). Kızılçam (Pinus brutia)'da fidan tiplerinin morfolojik karakterlere etkisi. Bartın University International Journal of Natural and Applied Sciences, 1(1):43-47.

Pawson S.M, Brin A, Brockerhoff E.G, Lamb D, Payn T.W, Paquette A, Parrotta J.A (2013). Plantation forests, climate change and biodiversity. Biodivers. Conserv., 22:1203-1227.

Sala O.E, Chapin F.S, Armesto J.J, Berlow E, Bloomfield J, Dirzo R, Huber-Sanwald E, Huenneke L.F, Jackson R.B, Kinzig A, Leemans R, Lodge D.M, Mooney H.A, Oesterheld M, Poff N.L, Sykes M.T, Walker B.H, Walker M, Wall D.H (2000). Global biodiversity scenarios for the year 2100. Science, 287:1770-1774.

Şıklar S, Öztürk H, Alan M (2017). Kızılçam (Pinus brutia Ten.) genetik 1slah çalışmalarının endüstriyel ağaçlandırmaların verimliliğine etkisi. 2023'e Doğru 4. Doğa ve Ormancılık Sempozyumu, 3-6 Aralık Antalya.

ŞimşekY (1993). Orman ağaçları 1slahına giriş. Ormancılık Araştırma Enstitüsü Yayınları, Muhtelif Yayınlar Serisi, No:65, Ankara.

Thomas, C.D., Cameron, A., Green, R.E., Bakkenes, M., Beaumont, L.J., Collingham, Y.C., Erasmus, B.F.N., de Siqueira, M.F., Grainger. A,, Hannah, L., Hughes, L., Huntley, B., van Jaarsveld, A.S., Midgley, G.F., Miles, L., Ortega-Huerta, M.A., Peterson, A.T., Phillips, O.L., Williams, S.E., 2004. Extinction risk from climate change. Nature, 427(6970):145-148.
Tolay U (1983). Hendek orman fidanlığında Uludağ göknarı (Abies bormülleriana Mattf.)'ın yetiştirme tekniği ile fidan kalitesi ve dikim başarısı arasındaki ilişkiler üzerine araştırmalar. Kavak ve Hızlı Gelișen Yabancı Tür Orman Ağaçları Araștırma Enstitüsü, İzmit.

Yahyaoğlu Z, Atasoy H (1983). Islah çalışmaları. KTÜ Orman Fakültesi Dergisi, 6(2):416-434.

Yahyaoğlu Z, Atasoy H (1988). Doğu Karadeniz yöresinde tür ve orijin denemeleri, KÜ Orman Fakültesi Dergisi, 6(1):28-42.

Y1lmazer C, Bilir N (2016). Effect of seedling type in morphology and quality of brutian pine (Pinus brutia Ten.) seedlings. IJSRST, 2(5):237-240.

Yücedağ C, Gezer A, Orhan H (2010). The genetic variation in Crimean juniper populations from the Lakes District of Turkey. Romanian Biotechnological Letters, 15(4):5487-5492.

Ulusan M.D, Bilir N (2008). Broad-sense heritability for seedling characters and its importance for breeding in Scots pine. Journal of Science of Suleyman Demirel University, 3(2):133-138.

Üçler A.Ö, Gülcü S, Bilir N (2000). Anadolu Karaçamı ve Kızılçam (Pinus brutia)'da tohum kaynağı-morfolojik fidan kalitesi ilişkileri. II. Ulusal Fidancılık Sempozyumu, 25-29 Eylül, İzmir.

Ürgenç S (1982). Orman ağaçları 1slahı. İstanbul Üniversitesi Orman Fakültesi Yayınları, İstanbul.

www. ogm.gov.tr (2020). Ormancilık istatistikleri. Orman Genel Müdürlüğü web sitesi, Ankara. 